\title{
APLIKASI TEORI KONTROL OPTIMAL PADA MODEL INFEKSI VIRUS HEPATITIS B
}

\author{
YULANDA MARDIANA PUTRI, MUHAFZAN, AHMAD IQBAL BAQI \\ Program Studi S1 Matematika, \\ Fakultas Matematika dan Ilmu Pengetahuan Alam, Universitas Andalas, \\ Kampus UNAND Limau Manis Padang, Indonesia. \\ email :yulanda0485@gmail.com,muhafzan@sci.unand.ac.id,baqi@sci.unand.ac.id
}

Diterima 12 Juni 2021 Direvisi 22 Juni 2021 Dipublikasikan 26 Juli 2021

\begin{abstract}
Abstrak. Dalam artikel ini dipelajari aplikasi teori kontrol optimal model penyebaran virus Hepatitis B pada seorang individu. Konstrain berbentuk model infeksi virus Hepatitis B dibagi atas tiga kompartemen, yaitu kompartemen jumlah sel target yang tidak terinfeksi (dinotasika dengan $T$ ), kompartemen jumlah sel target yang terinfeksi (dinotasikan dengan $I$ ) dan kompartemen jumlah virus virus Hepatitis B bebas yang ada dalam tubuh seseorang (dinotasikan dengan $V$ ). Dengan memasukkan level efisiensi terapi obat antiretroviral dalam menghambat infeksi baru $\left(u_{1}\right)$ dan level efisiensi terapi obat antiretroviral dalam menghambat replikasi virus $\left(u_{2}\right)$ sebagai dua variabel pengontrol ke dalam model infeksi virus Hepatitis B diperoleh suatu permasalahan kontrol optimal. Permasalahan kontrol optimal disini adalah mendapatkan level $u_{1}$ dan $u_{2}$ yang memenuhi model infeksi virus Hepatitis B sedemikian sehingga jumlah sel target yang tidak terinfeksi dimaksimalkan. Suatu simulasi numerik menggunakan metode Runge Kutta orde 4 diimplementasikan untuk melihat dinamika variabel $T, I$, dan $V$ terhadap waktu.
\end{abstract}

Kata Kunci: Kontrol optimal, model dasar infeksi virus, infeksi virus hepatitis B, metode Runge Kutta

\section{Pendahuluan}

Hepatitis B adalah peradangan organ hati yang disebabkan oleh infeksi virus Hepatitis B. Infeksi virus Hepatitis B merupakan masalah kesehatan utama masyarakat di dunia termasuk di indonesia yang dapat menyebabkan sirosis (pengerasan hati) dan kanker hati. Dalam literatur [1] dinyatakan bahwa pada tahun 2020 diperkirakan lebih dari 2 milyar penduduk dunia telah terinfeksi virus Hepatitis B dan sekitar 240 juta orang diantaranya mengidap Hepatitis kronik. Selain itu kematian yang disebabkan oleh Hepatitis B diperkirakan 600.000 orang setiap tahunnya. Virus Hepatitis B menginfeksi hati secara akut maupun kronis dan dapat menyebabkan kematian.

*Penulis Korespondensi 
Jika seseorang yang terinfeksi Hepatitis B akut biasanya tidak perlu mekakukan pengobatan. Sedangkan jika seseorang terinfeksi Hepatitis B kronis maka perlu melakukan pengobatan untuk mengurangi resiko sirosis dan kanker hati [9]. Menurut World Health Organization (WHO) sampai saat ini belum ada obat yang dapat menghilangkan infeksi virus Hepatitis B secara menyeluruh, namun terapi obat antiretroviral dapat digunakan untuk mengendalikan infeksi dan menekan penyebaran virus Hepatitis B.

Dalam studi ilmu pengetahuan bidang matematika, para ahli matematika ikut berperan dalam pencegahan penyebaran penyakit Hepatitis B , salah satu perannya yaitu dalam mengkonstruksikan dinamika penyebaran infeksi virus Hepatitis B dalam bentuk model matematika. Model penyebaran infeksi virus Hepatitis B dapat diamati dari segi internal (di dalam tubuh) dan eksternal (di luar tubuh). Pada penelitian ini akan dibahas mengenai model penyebaran infeksi virus Hepatitis B dalam tubuh dengan pemberian kontrol berupa obat terapi antiretroviral, dimana akan dilihat efisiensi obat terapi tersebut dalam menghambat infeksi baru dan menghambat replikasi virus. Model pada penelitian ini merujuk pada artikel yang ditulis oleh Nowak, dkk [6] dan K.Hattaf, dkk [2]. Model tersebut terbagi menjadi tiga kelompok yaitu jumlah sel target yang tidak terinfeksi, jumlah sel target yang terinfeksi dan jumlah virus Hepatitis B yang ada dalam tubuh seseorang. Penelitian ini bertujuan untuk mengkaji pengaruh pemberian kontrol berupa obat antiretroviral agar jumlah partikel virus dalam darah (viral load) menurun sedemikian sehingga jumlah sel target yang tidak terinfeksi virus Hepatitis B maksimum.

\section{Landasan Teori}

\subsection{Model Matematika Infeksi Virus Hepatitis B}

Nowak, dkk dalam [6] memformulasikan suatu model matematika yang memperlihatkan hubungan antara jumlah sel target yang tidak terinfeksi oleh virus Hepatitis B(dinotasikan dengan $T$ ), jumlah sel target yang terinfeksi oleh virus Hepatitis $\mathrm{B}$ (dinotasikan dengan $I$ ), dan jumlah virus Hepatitis B bebas yang ada dalam tubuh seseorang (dinotasikan dengan $V$ ). Dengan mengansumsikan bahwa infeksi virus Hepatitis B terjadi secara internal di dalam tubuh, tidak ada virus lain yang menyerang tubuh selain virus Hepatitis B, dan diasumsikan juga sel target yang sudah terinfeksi virus Hepatitis B tidak bisa sehat secara alami serta diasumsikan laju pertumbuhan sel target dalam tubuh konstan. Model persamaan diferensial biasa diberikan sebagai berikut :

$$
\begin{aligned}
\frac{d T}{d t} & =\lambda-d T-\beta V T \\
\frac{d I}{d t} & =\beta V T-\delta I \\
\frac{d V}{d t} & =r I-c V,
\end{aligned}
$$

dengan parameter-parameter didefinisikan dalam Tabel 1. 
Tabel 1. Deskripsi parameter model 2.1

\begin{tabular}{|c|l|}
\hline Parameter & \multicolumn{1}{|c|}{ Keterangan } \\
\hline$d$ & Laju kematian sel target yang sehat secara alami \\
\hline$\lambda$ & Laju pertumbuhan sel target baru \\
\hline$\beta$ & Laju infeksi virus terhadap sel target baru \\
\hline$\delta$ & Laju kematian sel target yang terinfeksi \\
\hline$c$ & Laju pembersihan virus bebas \\
\hline$r$ & Laju replikasi virus \\
\hline
\end{tabular}

\subsection{Teori Kontrol Optimal}

Kontrol optimal merupakan suatu metode optimasi matematika yang digunakan untuk menentukan variabel pengontrol atau variabel keputusan yang memenuhi suatu sistem persamaan diferensial dan mengoptimalkan suatu fungsi tujuan [3]. Secara umum, formulasi masalah kontrol optimal diberikan sebagai berikut. Diberikan suatu fungsi objektif

$$
J(\mathbf{u})=S\left(\mathbf{x}\left(t_{f}\right), t_{f}\right)+\int_{t_{0}}^{t_{f}} F(\mathbf{x}, \mathbf{u}, t) d t
$$

dan suatu sistem persamaan diferensial

$$
\text { s.t } \quad \dot{\mathbf{x}}=\mathbf{f}(\mathbf{x}, \mathbf{u}, t), \quad \mathbf{x}\left(t_{0}\right)=\mathbf{x}_{0}, \quad \mathbf{x}\left(t_{f}\right) \text { bebas, }
$$

dengan $\mathbf{x}=\mathbf{x}(t) \in \mathbb{R}, \mathbf{u}=\mathbf{u}(t) \in \mathbb{R}, \mathbf{x}\left(t_{f}\right) \in \mathbb{R}, t \geq 0$. Dalam hal ini $t_{0}$ merupakan waktu awal dan $t_{f}$ merupakan waktu akhir, $x$ adalah variabel keadaan, $u$ adalah variabel kontrol, dan $t$ adalah waktu. Masalah kontrol optimal dalam hal ini adalah mendapatkan pengontrol $u$ yang memenuhi sistem (2.3) sedemikian sehingga fungsi objektif $J$ bernilai maksimum atau minimum [4].

Syarat perlu agar $u^{*}$ memaksimumkan atau meminimumkan $J[11]$.

$$
\begin{aligned}
& \frac{\partial H}{\partial \mathbf{u}}=0, \\
& \dot{\mathbf{p}}=-\frac{\partial H}{\partial \mathbf{x}}, \\
& \mathbf{p}\left(t_{f}\right)=\frac{\partial S\left(\mathbf{x}\left(t_{f}\right), t_{f}\right)}{\partial \mathbf{x}\left(t_{f}\right)} .
\end{aligned}
$$

Syarat cukup agar $\mathbf{u}^{*}$ memaksimumkan $J$ adalah $\frac{\partial^{2} H}{\partial \mathbf{u}^{2}}<0$ dan meminimumkan $J$ adalah $\frac{\partial^{2} H}{\partial \mathbf{u}^{2}}>0[11]$.

\subsection{Metode Runge Kutta orde 4}

Metode Runge Kutta adalah metode yang digunakan untuk menyelesaikan masalah nilai awal pada persamaan diferensial biasa orde satu [10]. Metode ini sering digunakan karena metode runge kutta orde 4 memiliki tingkat ketelitian 
solusi yang lebih tinggi dibandingkan dengan metode Runge Kutta yang berorde di bawahnya [7]. Dalam penelitian ini metode Runge Kutta yang digunakan adalah metode Runge Kutta orde 4 untuk menyelesaikan suatu model matematika infeksi virus Hepatitis B yang telah dimodelkan dalam bentuk persamaan diferensial.

Diberikan persamaan diferensial sebagai berikut.

$$
\dot{y}(t)=f(t, y(t)), \quad y\left(t_{0}\right)=y_{0}
$$

yang dalam hal ini $y$ bisa berbentuk skalar dan juga bisa berbentuk vektor. $t_{0}$ adalah waktu awal dan $y_{0}$ adalah nilai $y$ pada waktu $t_{0}, h$ merupakan ukuran langkah dengan $h>0$. Rumus iterasi dari metode runge kutta orde 4 adalah sebagai berikut.

$$
y_{n+1}=y_{n}+\frac{1}{6}\left(k_{1}+2 k_{2}+2 k_{3}+k_{4}\right)
$$

untuk $n=1,2,3, \cdots$ sedemikian sehingga

$$
\begin{aligned}
k_{1} & =h f\left(t_{n}, y_{n}\right), \\
k_{2} & =h f\left(t_{n}+\frac{h}{2}, y_{n}+\frac{h}{2} k_{1}\right), \\
k_{3} & =h f\left(t_{n}+\frac{h}{2}, y_{n}+\frac{h}{2} k_{2}\right), \\
k_{4} & =h f\left(t_{n}+h, y_{n}+h k_{3}\right) .
\end{aligned}
$$

\section{Model Matematika Infeksi Virus Hepatiris B dengan Kontrol}

Model matematika infeksi virus Hepatitis B dengan pemberian kontrol, dimana kontrol yang diberikan adalah terapi antiretroviral. Terapi ini berupa pemberian obat antiretroviral yang digunakan untuk mengatasi infeksi virus Hepatitis B dengan cara menghambat hepatitis B pada tahap siklus hidupnya. Dengan mengansumsikan bahwa infeksi virus Hepatitis B terjadi secara internal di dalam tubuh, tidak ada virus lain yang menyerang tubuh selain virus Hepatitis B, dan diasumsikan juga sel target yang sudah terinfeksi virus Hepatitis B tidak bisa sehat secara alami serta diasumsikan laju pertumbuhan sel target dalam tubuh konstan. Model matematika infeksi virus Hepatitis B dengan kontrol sebagai berikut [2].

$$
\begin{aligned}
\frac{d T}{d t} & =\lambda-d T-\left(1-u_{1}\right) \beta V T, \\
\frac{d I}{d t} & =\left(1-u_{1}\right) \beta V T-\delta I, \\
\frac{d V}{d t} & =\left(1-u_{2}\right) r I-c V
\end{aligned}
$$

dengan nilai awal $T(0)=T_{0}, I(0)=I_{0}$ dan $V(0)=V_{0}$. Kontrol $u_{1}$ adalah efisiensi terapi obat antiretroviral dalam menghambat infeksi baru dan kontrol $u_{2}$ adalah efisiensi terapi obat antiretroviral dalam menghambat replikasi virus. Dengan $u_{i} \in$ $[0,1], i=0,1$. Jika $u_{1}, u_{2}=1$ ini berarti penghambatan $100 \%$ efektif namun jika 
264 Yulanda Mardiana Putri dkk.

$u_{1}, u_{2}=0$ tidak terjadi penghambatan.

Didefinisikan fungsi tujuan sebagai berikut :

$$
J\left(u_{1}, u_{2}\right)=\int_{t_{0}}^{t_{f}}\left(T-\left[\frac{A_{1}}{2} u_{1}^{2}+\frac{A_{2}}{2} u_{2}^{2}\right]\right) d t,
$$

dengan parameter $A_{1} \geq 0$ merupakan bobot biaya kontrol $u_{1}$ dan $A_{2} \geq$ 0 merupakan bobot biaya kontrol $u_{2}$. Sistem dinamik (3.1) bersama dengan fungsi tujuan (3.2) membentuk suatu masalah kontrol optimal. Masalah kontrol optimal disini adalah menentukan pengotrol $u_{i} \in[0,1], i=1,2$ yang memenuhi sistem dinamik (3.1) sedemikian sehinga fungsi tujuan $J$ bernilai maksimum, yaitu memaksimumkan jumlah sel target yang tidak terinfeksi oleh virus Hepatitis B. Untuk mendapatkan pengontrol $u_{i}, i=1,2$ tersebut gunakan syarat perlu dan syarat cukup yang sudah diperkenalkan pada subbab 2.2. Fungsi Hamilton untuk masalah ini adalah

$$
\begin{aligned}
H & =T-\left[\frac{A_{1}}{2} u_{1}^{2}+\frac{A_{2}}{2} u_{2}^{2}\right]+p_{1}\left(\lambda-d T-\left(1-u_{1}\right) \beta V T\right) \\
& +p_{2}\left(\left(1-u_{1}\right) \beta V T-\delta I\right)+p_{3}\left(\left(1-u_{2}\right) r I-c V\right) .
\end{aligned}
$$

Penggunaan syarat (2.4) memberikan:

$$
\begin{aligned}
\dot{p}_{1}=-\frac{\partial H}{\partial T} & =-1+\lambda_{1} d+\left(p_{1}-p_{2}\right)\left(1-u_{1}\right) \beta V \\
\dot{p}_{2}=-\frac{\partial H}{\partial I} & =p_{2} \delta-p_{3}\left(1-u_{2}\right) r \\
\dot{p}_{3}=-\frac{\partial H}{\partial V} & =p_{3} c+\left(p_{1}-p_{2}\right)\left(1-u_{1}\right) \beta T \\
p_{i}\left(t_{f}\right) & =0, \quad i=1,2,3
\end{aligned}
$$

$$
\begin{aligned}
& \frac{\partial H}{\partial u_{1}}=-A_{1} u_{1}+p_{1} \beta V T-p_{2} \beta V T=0, \text { menghasilkan } u_{1}^{*}=\frac{\left(p_{1}-p_{2}\right) \beta V T}{A_{1}}, \\
& \frac{\partial H}{\partial u_{2}}=-A_{2} u_{2}-p_{3} r I=0, \text { menghasilkan } u_{2}^{*}=-\frac{p_{3} r I}{A_{2}} .
\end{aligned}
$$

Karena $u_{i} \in[0,1], i=1,2$ maka diperoleh kontrol optimal sebagai berikut:

$$
u_{1}^{*}=\left\{\begin{array}{cccr}
0 & , & \text { jika } & \frac{\left(p_{1}-p_{2}\right) \beta V T}{A_{1}} \leq 0 \\
\frac{\left(p_{1}-p_{2}\right) \beta V T}{A_{1}} & & , \text { jika } & 0<\frac{\left(p_{1}-p_{2}\right) \beta V T}{A_{1}}<1 \\
1 & , & \text { jika } & \frac{\left(p_{1}-p_{2}\right) \beta V T}{A_{1}} \geq 1
\end{array}\right.
$$

dan

$$
u_{2}^{*}=\left\{\begin{array}{cccc}
0 & , & \text { jika } & \frac{-p_{3} r I}{A_{2}} \leq 0 \\
\frac{-p_{3} r I}{A_{2}} & , & \text { jika } & 0<\frac{-p_{3} r I}{A_{2}}<1 \\
1 & , & \text { jika } & \frac{-p_{3} r I}{A_{2}} \geq 1 .
\end{array}\right.
$$


Dapat diperiksa bahwa syarat cukup

$$
\left[\frac{\partial^{2} H}{\partial \mathbf{u}^{2}}\right]=\left[\begin{array}{cc}
-A_{1} & 0 \\
0 & -A_{2}
\end{array}\right]<0
$$

yang menunjukkan bahwa $\mathbf{u}^{*}=\left(u_{1}^{*}, u_{2}^{*}\right)$ memaksimumkan fungsi tujuan.

\section{Simulasi Numerik}

Pada sub bab ini akan dianalisis mengenai hasil simulasi yang membandingkan dinamika masing masing populasi sebelum dan setelah pemberian kontrol optimal ke dalam sistem dengan model infeksi virus Hepatitis B yang ditunjukkan melalui grafik, dengan menginputkan nilai nilai parameter yang disajikan dalam Tabel 2. Dengan menggunakan software MATLAB2014a, akan ditunjukkan kondisi sistem model infeksi virus Hepatitis B sebelum dan setelah pemberian kontrol optimal dalam grafik, dengan nilai awal $T(0)=5.5556 \times 10^{7}, I(0)=1.1111 \times$ $10^{7}$, dan $V(0)=6.3096 \times 10^{9}$.

Tabel 2. Nilai Parameter Model (3.1)

\begin{tabular}{|c|c|}
\hline Parameter & Nilai \\
\hline$c$ & 0.67 \\
\hline$h$ & 1 \\
\hline$d$ & $3.7877 \times 10^{-3}$ \\
\hline$\delta$ & $1.2344 \times 10^{-2}$ \\
\hline$\lambda$ & $2.525133 \times 10^{5}$ \\
\hline$r$ & $8.3289 \times 10^{2}$ \\
\hline$\beta$ & $1.9810 \times 10^{-13}$ \\
\hline
\end{tabular}

Gambar (a) menunjukkan bahwa setelah pemberian kontrol berupa obat antiretroviral, jumlah sel target yang tidak terinfeksi virus Hepatitis B meningkat. Pada Gambar (b), jumlah sel target yang terinfeksi pada waktu akhir tf $=60$ (hari) adalah $5.2978 \times 10^{6}$ dalam kasus dengan kontrol dan $1.1378 \times 10^{7}$ tanpa kontrol, maka efisiensi terapi obat dalam menghambat infeksi baru adalah $68,23 \%$. Gambar (c) menunjukkan bahwa setelah diberi kontrol, virus Hepatitis B menurun ke nol. Jumlah virus bebas dengan kontrol pada waktu akhir adalah 0 dan tanpa kontrol berjumlah $1.407 \times 10^{10}$ dan jumlah total dalam menghambat replikasi virus pada akhir program kontrol adalah $1.407 \times 10^{10}$, maka efisiensi terapi obat dalam menghambat replikasi virus bebas $100 \%$. Gambar (d) yang diberikan dibawah ini menunjukkan kontrol optimal $u_{1}$ dan $u_{2}$ dalam menghambat infeksi baru dan menghambat repliksi virus 


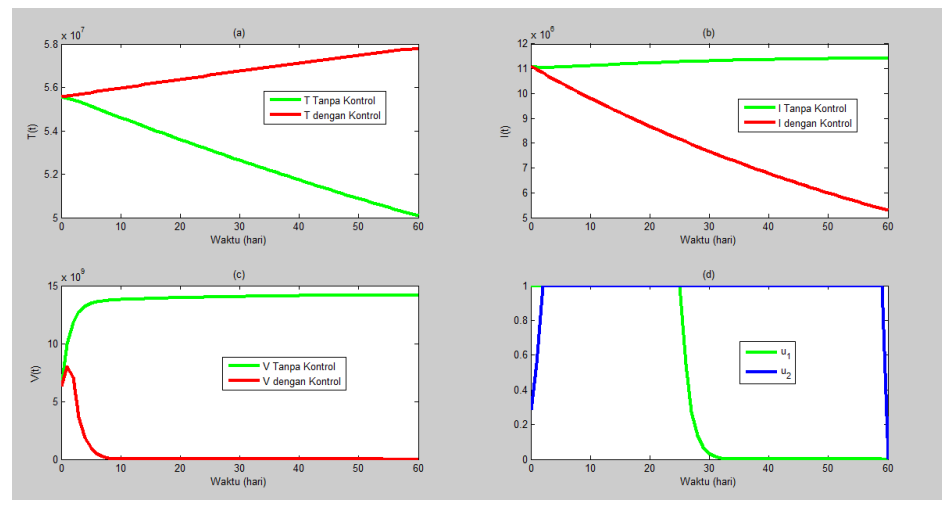

Gambar 1: Grafik jumlah sel yang tidak terinfeksi, terinfeksi, virus bebas dan grafik kontrol optimal

\section{Kesimpulan}

Berdasarkan hasil pembahasan yang telah dijelaskan pada bab sebelumnya, dapat disimpulkan bahwa:

(1) Model matematika infeksi virus Hepatitis B dengan melibatkan dua variabel kontrol.

$$
\begin{aligned}
\frac{d T}{d t} & =\lambda-d T-\left(1-u_{1}\right) \beta V T, \\
\frac{d I}{d t} & =\left(1-u_{1}\right) \beta V T-\delta I, \\
\frac{d V}{d t} & =\left(1-u_{2}\right) r I-c V,
\end{aligned}
$$

(2) Kontrol optimal yang diperoleh dalam upaya memaksimumkan jumlah sel target yang tidak terinfeksi adalah

$$
u_{1}^{*}=\left\{\begin{array}{cccrl}
0 & , & \text { jika } & \frac{\left(p_{1}-p_{2}\right) \beta V T}{A_{1}} \leq 0 \\
\frac{\left(p_{1}-p_{2}\right) \beta V T}{A_{1}} & & , \text { jika } & 0<\frac{\left(p_{1}-p_{2}\right) \beta V T}{A_{1}}<1 \\
1 & , & \text { jika } & \frac{\left(p_{1}-p_{2}\right) \beta V T}{A_{1}} \geq 1,
\end{array}\right.
$$

dengan $u_{1}$ adalah efisiensi terapi obat antiretroviral dalam menghambat infeksi baru.

$$
u_{2}^{*}=\left\{\begin{array}{cccc}
0 & , & \text { jika } & \frac{-p_{3} r I}{A_{2}} \leq 0 \\
\frac{-p_{3} r I}{A_{2}} & , & \text { jika } & 0<\frac{-p_{3} r I}{A_{2}}<1 \\
1 & , & \text { jika } & \frac{-p_{3} r I}{A_{2}} \geq 1,
\end{array}\right.
$$

dengan $u_{2}$ adalah efisiensi terapi obat antiretroviral dalam menghambat replikasi virus. 
Aplikasi Teori Kontrol Optimal Pada Model Infeksi Virus Hepatitis B 267

(3) Setelah dilakukan simulasi numerik pada model infeksi virus Hepatitis B dengan menggunakan aplikasi Matlab R2014a dapat disimpulkan bahwa pemberian obat antiretroviral dapat meningkatkan jumlah sel target yang tidak terinfeksi virus Hepatitis B, mengurangi jumlah sel target yang terinfeksi virus Hepatitis $\mathrm{B}$ dan menekan penyebaran virus Hepatitis B dalam tubuh.

\section{Ucapan Terima kasih}

Penulis mengucapkan terima kasih kepada Bapak Admi Nazra, Ibu Hazmira Yozza, dan Bapak Budi Rudianto yang telah memberikan masukan dan saran sehingga artikel ini dapat diselesaikan dengan baik.

\section{Daftar Pustaka}

[1] Departeman Kesehatan RI, 2020, Buku Saku Hepatitis, Jakarta

[2] K. Hattaf, M. Rachik, S. Saadi and N. Yousfi. 2009. Optimal Control of Treatment in a Basic Virus Infection Model. Applied Mathematical Science. Volume 3, Number 20: 949 - 958

[3] Lenhart, S., and J. T. Workman. 2007. Optimal Control Applied to Biological Models. Chapman and Hall, CRC Press. New York

[4] Lewis F. L, Syrmos V. L. 1995. Optimal Control, Willy Interscience, Canada

[5] L. Min, Y. Su, and Y. Kuang. 2008. Mathematical analysis of a basic model of virus infection with application to HBV infection. Rocky Mountain J. of mathematics. Volume 38, Number 5, 1573 - 1585

[6] M. Nowak, S. Bonhoeffer, A. Hill, R. Boehme, H. Thomas, H. McDade. 1996. Viral dynamics in hepatitis B infection. Proc Natl Acad Sci USA. Vol 93: 43984402

[7] M. Rinaldi. 2006. Metode Numerik. Bandung: Informatika

[8] Okamoto T, Suzuki T, Kusakabe S, Tokunaga M, Hirano J, Miyata Y, Matsuura Y. 2017. Regulation of Apoptosis during Flavivirus Infection. Viruses. Volume 9, Number 9, 243

[9] Pusat data dan informasi Kementerian Kesehatan RI. 2020. Situasi dan Analisis Hepatitis. Jakarta

[10] Sasongko, S. 2010. Metode numerik dengan scilab. Yogyakarta: Andi Yogyakarta

[11] S. Naidu. 2002. Optimal Control System. USA: CRRC Press

[12] World Health Organization, Hepatitis B Report. 2020 